\title{
IMPLEMENTASI MODEL PEMBELAJARAN TEAMS GAMES TOURNAMENT MENINGKATKAN KETERAMPILAN KOLABORATIF PESERTA DIDIK KELAS 4 SD
}

\author{
One Teladaningsih ${ }^{1}$, Mawardi ${ }^{2}$, Indi Huliana ${ }^{3}$ \\ 1,2PPG SD-FKIP, Universitas Kristen Satya Wacana \\ ${ }^{3}$ Sekolah Dasar Negeri Tingkir Lor 02, Salatiga \\ 1oneteladaningsih@gmail.com, ${ }^{2}$ mawardi@staff.uksw.edu, \\ 3indihulyana@gmail.com
}

\begin{abstract}
The problem of thematic learning process in SD Negeri Tingkir Lor 02 is collaborative skills that are still low, so that the impact on student learning outcomes is not satisfactory. Based on these problems it is necessary to conduct classroom action research in two cycles, each cycle consisting of five steps: planning, implementation, observation, evaluation, and reflection. The purpose of this study was to improve collaborative skills through the application of the Teams Games Tournament learning model. Instruments collecting data using an observation sheet are used to collect data, collaborative skills, teacher activity data and student activity data, written tests to compare and study the increase in collaborative learning carried out by students, and documentation to confirm the data obtained in the observation. Data analysis techniques use descriptive categorical and comparative techniques. The results showed an increase in collaborative skills that were seen to increase the average score of students in each cycle. The average collaborative skills of the first cycle amounted to 78.22, in the second cycle increased to 93.18 so that there was an increase in collaborative skills of $16.05 \%$. Based on the description above it can be concluded that the application of the Teams Games Tournament (TGT) model can improve collaborative skills.
\end{abstract}

Keywords: Games Tournament Team, collaborative skills

\section{ABSTRAK}

Permasalahan dalam proses pembelajaran tematik di SD Negeri Tingkir Lor 02 adalah bahwa keterampilan kolaboratif masih rendah, sehingga berdampak pada hasil belajar peserta didik yang belum memuaskan. Berdasarkan masalah tersebut maka perlu dilakukan penelitian tindakan kelas yang dilakukan dalam dua siklus, masing-masing siklus terdiri dari lima tahap yaitu perencanaan, pelaksanaan tndakan, observasi, evaluasi, dan refleksi. Tujuan penelitian ini untuk meningkatkan keterampilan kolaboratif melalui implementasi model pembelajaran Teams Games Tournament. Instrument pengumpulan data menggunakan lembar observasi digunakan untuk mengumpulkan data keterampilan kolaboratif, data 
aktivitas guru dan data aktivitas peserta didik, tes tertulis untuk membandingkan dan mengetahui peningkatan pembelajaran kolaboratif yang dilakukan oleh peserta didik, dan dokumentasi untuk mengkonfirmasikan data yang diperoleh dalam observasi. Teknik analisis data menggunakan teknik deskriptif kategoris dan komparatif. Hasil penelitian menunjukkan adanya peningkatan keterampilan kolaboratif yang terlihat peningkatan rata-rata skor peserta didik setiap siklus. Rata-rata keterampilan kolaboratif dari siklus I sebesar 78,22, pada siklus II meningkat menjadi 93,18 sehingga diperoleh persentase peningkatan keterampilan kolaboratif sebesar 16,05\%. Berdasarkan uraian diatas dapat disimpulkan bahwa penerapan model Teams Games Tournament (TGT) dapat meningkatkan keterampilan kolaboratif.

Kata kunci: Teams Games Tournament, keterampilan kolaboratif

\section{A. Pendahuluan}

Pembelajaran merupakan suatu bantuan untuk memperoleh ilmu dan pengetahuan yang diberikan oleh guru agar mampu membentuk sikap dan pribadi yang baik. Menurut permendikbud No. 22 Tahun 2016 dijelaskan bahwa suatu proses pembelajaran merupakan kerangka kerja kurikulum 2013 dilakukan secara interaktif, inspiratif, menyenangkan, menantang, memotivasi peserta didik dalam berpartisipasi aktif, serta memberikan kesempatan bagi peserta didik untuk berkreativitas dan kemandirian sesuai dengan bakat, minat, dan perkembangan fisik serta psikologis peserta didik dan untuk memperkuat pendektan ilmiah (Scientefic), tematik terpadu (tematik antar mata pelajaran), dan tematik (dalam suatu mata pelajaran) guru menerapkan pembelajaran yang berbasis penyikapan/ penelitian (discover/ inkuiri).

Kurikulum 2013 adalah kurikulum yang mengembangkan sikap (afektif), pengetahuan (kognitif) dan keterampilan (psikomotorik) serta menerapkannya dalam kehidupan sehari-hari baik di keluarga, sekolah, dan masyarakat. Pembelajaran yang terjadi di kurikulum 2013 adalah sebuah pembelajaran yang berbasis tematik integratif. Peserta didik tidak hanya menguasai aspek pengetahuannya saja, tetapi juga mencakup sikap dan keterampilannya. Hal ini melibatkan pembelajaran yang aktif, efektif dan kreatif dengan rasa ingin tahu yang tinggi, kerja sama dengan kegiatan berkelompok dan kemampuan 
peserta didik dalam psikomotorik. Kegiatan pembelajaran yang aktif, efektif dan kreatif dapat didukung dengan beberapa model pembelajaran yang mampu membantu guru dalam mencapai tujuan pembelajaran.

Kegiatan pembelajaran yang aktif, efektif dan kreatif dilakukan dengan berinteraksi dan bekerjasama secara kolaborasi dalam sebuah kelompok. Keterampilan bekerjasama dengan teman sangat dibutuhkan, dan merupakan suatu aspek sosial yang harus dimiliki oleh setiap peserta didik dalam kegiatan belajar mengajar.

Kenyataannya proses pembelajaran yang terjadi di SD Negeri Tingkir Lor 02 berdasarkan observasi awal yang dilakukan, ada beberapa masalah yang peneliti temukan ketika proses pembelajaran berlangsung, diantara adalah : guru masih cenderung mendominasi kegiatan pembelajaran, guru hanya sebatas menggunakan papan tulis tidak menggunakan media pembelajaran lainnya yang relevan untuk menunjang pembelajaran, guru belum memberikan reward kepada peserta didik yang aktif berpartisipasi dalam kegiatan pembelajaran, dalam pembelajaran

guru

belum

mengembangkan

berbagai

keterampilan

peserta

didik

berhubungan dengan interaksi sosial sesama teman atau disebut keterampilan sosial, selain menerapkan metode ceramah guru juga menerapkan kegiatan pembelajaran berkelompok namun tidak sepenuhnya berhasil.

Berdasarkan permasalahanpermasalahan di atas, salah satu masalah yang harus segera diatasi adalah tentang kemampuan peserta didik dalam hal keterampilan yang harus dimiliki dalam pembelajaran kurikulum 2013. Keterampilan ini relevan untuk dikembangkan dalam implementasi pembelajaran kurikulum 2013, agar kelak para peserta didik dapat hidup sebagai warga masyarakat, warga negara, warga dunia yang dapat berperan dalam lingkupnya.

Hasil kajian menemukan bahwa model pembelajaran Teams Game Tournament (TGT) berpotensi untuk meningkatkan keterampilan kolaboratif peserta didik dalam pembelajaran. Karena model pembelajaran Teams Game Tournament (TGT) merupakan salah satu pembelajaran yang dilakukan 
secara berkelompok dan merupakan model pembelajaran

yang menggunakan

pendekatan

komunikatif, dimana pendekatan yang memungkinkan peserta didik untuk terlibat aktif. Menurut Huda (2018:215) pembelajaran yang berbasis komunikatif memungkinkan peserta didik untuk mampu : membaca dan menulis dengan baik, belajar dengan orang lain, menggunakan media, menerima informasi, menyampaikan informasi.

Untuk memperbaiki keterampilan kolaboratif tersebut, maka akan diterapkan model pembelajaran Teams Game Tournament (TGT) sebagai upaya peningkatan keterampilan kolaboratif peserta didik kelas 4 di SD Negeri Tingkir Lor 02.

\section{B. Landasan Teori}

Model pembelajaran Teams Games Tournament (TGT) merupakan salah satu model pembelajaran kooperatif. Pada model pembelajaran Teams Games Tournament (TGT) setelah guru menyajikan materi, peserta didik dalam satu kelompok bekerja sama sebagai tim untuk mengerjakan lembar kerja dan belajar bersama untuk menghadapi permainan
(Games) dan pertandingan (Tournament). Model pembelajaran Teams Games Tournament (TGT) termasuk salah satu model pembelajaran Kooperatif yang mudah diterapkan melibatkan aktivitas seluruh peserta didik tanpa adanya perbedaan, melibatkan peran status peserta didik sebagai tutor sebaya, dan mengandung unsur permainan (Games) dan penghargaan (rewards). Menutut Hamdani (2011: 92) aktivitas peserta didik dengan model TGT memungkinkan peserta didik kegiatan pembelajaran dapat belajar lebih rileks disamping menumbuhkan tanggung jawab, kerjasama, pesaingan sehat dan keterlibatan belajar.

Menurut Slavin (2009: 163), model pembelajaran kooperatif tipe Teams Games Tournament (TGT) menggunakan permainan akademik. Pada Tournament, peserta didik mewakili timnya dengan anggota tim lain yang memiliki kemampuan akademik sama berdasarkan kinerja sebelumnya. Komponen-komponen dalam Teams Games Tournament (TGT) yang diungkapkan slavin yaitu presentasi kelas, belajar tim, dan turnamen berupa permainan. 
Rusman (2012: 224) menjelaskan bahwa TGT adalah salah satu tipe pembelajaran kooperatif yang menempatkan peserta didik dalam kelompok-kelompok belajar yang beranggotakan 5-6 peserta didik yang memiliki kemampuan, jenis kelamin, dan suku atau ras yang berbeda.

Jadi, model pembelajaran Teams Game Tournament (TGT) merupakan salah satu bentuk pembelajaran kooperatif, yang terdiri dari penyampaian materi, pengelompokan tim (Team), permainan (Game), pertandingan (Tournament), dan penghargaan kelompok. Model Teams Games Tournament (TGT) dapat menambah motivasi belajar, percaya diri dalam menyampaikan pendapat, toleransi terhadap teman, kerjasama bersama kelompok dan pemahaman materi peserta didik dalam belajar.

Partisipasi keaktifan peserta didik sangat berpengaruh pada proses perkembangan berpikir, emosi, dan sosial. Sebagian pendidik menyadari bahwa pembelajaran tidak hanya proses mentransfer ilmu saja, namun juga membuat anak menjadi cerdas, kritis, dan kreatif serta mampu bekerjasama memecahkan masalah yang berkaitan dengan kehidupan mereka sehari-hari. Hal ini dapat dilakukan dengan pembelajaran dengan berkelompok, seperti halnya pembelajaran kolaborasi, dimana siswa berkolaborasi dalam sebuah kelompok untuk menyelesaikan tugas.

Kolaborasi merupakan proses kegiatan belajar dalam merencanakan dan bekerja bersamasama, untuk menimbang perbedaan pandangan/ perspektif, dan untuk berpartisipasi dalam diskusi dengan cara sumbang saran, mendengarkan, dan mendukung orang lain menurut Grenstein (2012: 105) dalam Vivin (2018). Didalam kelas kolaborasi, peserta didik akan bekerja untuk membagi tujuan, belajar bersama, terlibat dalam tugas yang bermakna, dan membangun pengetahuan awal untuk menghasilkan ide-ide dan berbagai macam produk/artefak (Greenstein, (2012: 106) dalam Vivin (2018)).

Bordessa (2005) dalam Djoko (2013) juga menyatakan pentingnya seseorang peserta didik memiliki keterampilan kerjasama, dengan mengatakan bahwa peserta didik harus belajar untuk bekerjasama menuju satu tujuan, yakni adanya pemahaman bahwa tidak ada satu 
orangpun yang memiliki semua jawaban yang tepat, kecuali dengan bekerjasama.

Greenstein (2012) dalam Eka (2016) mengungkapkan bahwa keterampilan kolaboratif mahasiswa adalah keterampilan yang menekankan pada tugas spesifik dan berbagi tugas dalam kerja kelompok, membandingkan kesimpulan dan prosedur kerja kelompok, dan memberikan keleluasaan yang lebih besar pada siswa dalam kerja kelompok. Keterampilan kolaboratif memiliki empat aspek yaitu bekerja secara produktif, menghargai, berkompromi, berbagi dan kontribusi.

Pada keterampilan kolaboratif memiliki indikator menurut Zubaidah (2018: 21-22) antara lain bekerja produktif dengan menggunakan seluruh waktu secara efisien dalam menyelesaikan tugas dengan bekerja sama; menunjukkan rasa hormat dengan menghargai setiap anggota dalam berpendapat dan diskusi antar anggota; berkompromi sesama anggota secara fleksibel demi mencapai tujuan utama menyelesaikan masalah; serta tanggung jawab bersama dan setiap anggota berkontribusi dengan melakukan yang terbaik dan mengikuti apa yang ditugaskan.

Warso dan haryanto,(2012: 66-67) menjelaskan bahwa peserta didik yang bekerja dalam kelompokkelompok kecil cenderung belajar lebih banyak tentang materi ajar dan memiliki daya ingat yang lebih lama dibandingkan jika materi ajar tersebut disampaikan dengan bentuk yang lain.

Jadi, keterampilan kolaboratif merupakan kegiatan kerjasama yang tidak hanya meliputi kegiatan dalam berkelompok saja, namun juga meliputi kegiatan untuk melatih siswa dalam keaktifan berpendapat dalam kelompok selain itu, kerjasama merupakan aspek kepribadian yang penting, dan perlu dimiliki oleh setiap peserta didik baik disekolah maupun dalam kehidupan sosial di masyarakat.

Berdasarkan hasil penelitian yang menyerupai dengan peneliti yaitu penelitian Keke Citra Wahyu Avisca, Mawardi, dan Suhadi Astuti (2018: 129) melakukan penelitian tentang Peningkatan Critical Thinking dan Collaborative Skill Matematika Melalui Model Group Investigation Berbantuan Magic Ball. Hasil penelitian menunjukkan bahwa 
adanya peningkatan keterampilan Critical Thinking dan Collaborative terlihat dari peningkatan total skor peserta didik setiap siklus. Selanjutnya penelitian yang senada yaitu penelitian Eka Vasia Anggis (2016:493) tentang Penerapan Model Kooperatif JIGSAW berbasis Lesson Study untuk Meningkatkan Keterampilan Kolaboratif dan Hasil Belajar Kognitif. Penerapan model Jigsaw_LS dapat meningkatkan keterampilan kolaboratif sebesar $8,26 \%$ dan hasil belajar kognitif sebesar $1,56 \%$ dari siklus I ke siklus II. Hal yang sama dilakukan oleh Vivin Putri Devi, Wahyudi, Endang Indarini (2018) keterampilan kolaborasi mengalami peningkatan mulai dari pra siklus dengan kriteria sedang, siklus I kriteria sedang hingga siklus II menjadi kriteria tinggi dengan diberikan perlakuan menggunakan model pembelajaran kooperatif yaitu menggunakan Numbered Heads Together (NHT).

Berbeda dengan penelitian yang dilakukan oleh Suciyani Suaeb (2018: 146) hasil penelitian menunjukkan model pembelajaran Teams Games Tournament (TGT) merupakan model pembelajaran kooperatif yang mampu meningkatkan hasil belajar peserta
didik.Selanjutnya penelitian yang sejalan yaitu penelitian Rima Yusi Christian, Mawardi dan Suhandi Astuti (2018: 75), tentang Perbedaan Hasil Belajar Matematika Menggunakan Model Student Team Achievment Divisions (STAD) dan Teams Game Tournament (TGT) menunjukkan perbedaan hasil belajar yang signifikan. Data komparasi ratarata nilai posttest eksperimen 1 adalah 80,00 sedangkan rata-rata nilai posttest eksperimen 2 adalah 74,18 . Sama halnya dengan penelitian Ujiati Cahyaningsih (2017: 1) tentang Pengaruh Model Pembelajaran Kooperatif Tipe Team Games Tournament (TGT) Terhadap Hasil Belajar Matematika Siswa SD. Dalam penelitian ini ada pengaruh model pembelajaran kooperatif tipe TGT terhadap hasil belajar matematika aspek kognitif dan psikomotor pada siswa dan tidak ada pengaruh model pembelajaran kooperatif tipe TGT terhadap hasil belajar matematika aspek afektif pada siswa. Kemudian penelitian yang dilakukan Sri Wilujeng (2013: 45) model pembelajaran TGT dapat meningkatkan aktivitas dan hasil belajar Matematika materi Bangun Ruang pada siswa kelas IV dan 
meningkatkan performansi guru di SDN Muarareja 02 Tegal tahun pelajaran 2011/2012. Penelitian yang senada dilakukan oleh Kadek Yuni Artati (2017: 1), tentang Pengaruh Model Pembelajaran Kooperatif Tipe TGT Terhadap Hasil Belajar IPA Siswa Kelas V SD dengan hasil penelitian model pembelajaran kooperatif tipe TGT berpengaruh signifikan terhadap hasil belajar IPA pada siswa kelas V. selanjutnya Siti Era Harahap (2018: 101) melakukan penelitian tentang Meningkatkan Hasil Belajar PPKN Melalui Model Pembelajaran TGT (Team Games Tournament) Siswa Kelas 5 SD Negeri 164525 Tebing Tinggi. Pelajaran dengan model TGT pada materi pelajaran PPKN di kelas $5 \mathrm{SD}$ Negeri 164525 Tebing Tinggi memiliki dampak positif dalam meningkatkan hasil belajar siswa yang ditandai dengan peningkatan ketuntasan belajar siswa dalam setiap siklus, yaitu siklus. Selanjutnya penelitian Siti Maisaroh (2011: 150-169) dalam penelitiannya tentang Upaya Peningkatkan Motivasi dan Prestasi Belajar IPS Melalui Model Pembelajaran Kooperatif Tipe Teams Games Tournament. Peningkatan kualitas pembelajaran terjadi secara bertahap pada setiap siklus yang pada akhirnya dapat meningkatkan prestasi belajar. Senada dengan penilitian Anisa Eka Pratiwi (2018: 338) model pembelajaran dengan menggunakan model kooperatif tipe TGT menghasilkan prestasi belajar IPA yang lebih baik, sehingga terdapat pengaruh positif penggunaan model pembelajaran kooperatif tipe TGT terhadap prestasi belajar IPA siswa kelas V SD Negeri Gedongtengen Yogyakarta tahun ajaran 2016/2017. Begitu juga dengan Kadek Mita Wahyuni, Made Putra, dan I Wayan Darsana (2014) Terdapat pengaruh model pembelajaran Team Game Turnament (TGT) melalui variasi reinforcement terhadap hasil belajar IPS siswa kelas V SD Gugus III Batuan Sukawati tahun pelajaran 2013/2014.

\section{Metode Penelitian}

Jenis penelitian yang digunakan peneliti untuk memecahkan masalah keterampilan kolaboratif adalah penelitian tindakan kelas (PTK).

Setting penelitian yang digunakan oleh peneliti adalah setting kelas, data diperoleh selama proses pembelajaran berlangsung. Peneliti 
dibantu oleh satu orang guru kelas dan satu orang observer untuk melakukan pengamatan selama proses pembelajaran.

Pembelajaran di kelas merupakan penerapan model pembelajaran Teams Games Tournament dalam tema Daerah Tempat Tinggalku, subtema Keunikan Daerah Tempat Tinggalku. Penelitian dilakukan di SD Negeri Tingkir Lor 02 semester II, tahun ajaran 2018/2019. Subjek dalam penelitian ini adalah seluruh peserta didik kelas 4 SD Negeri Tingkir Lor 02 yang berjumalah 33 peserta didik, 15 laki-laki dan 18 perempuan.

Instrumen pengumpulan data yang diterapkan dalam penelitian berupa: 1) Lembar Observasi digunakan untuk mengumpulkan data keterampilan kolaboratif, data aktivitas guru dan data aktivitas peserta didik, 2) Tes Tertulis yang dilakukan setiap selesai siklus pembelajaran dikoreksi dan dianalisa untuk dibandingkan dan untuk mengetahui peningkatan pembelajaran kolaboratif yang dilakukan oleh peserta didik, 3) Dokumentasi untuk memperkuat data yang diperoleh dalam observasi dengan mencatat atau mengabadikan berupa foto atau video dan juga catatan-catatan yang dilakukan dalam penelitian oleh observer.

\section{Hasil dan Pembahasan}

\section{Hasil Penelitian}

Kondisi awal dilihat dari hasil observasi pembelajaran yang dilaksanakan pada bulan Januari 2019 di SD Negeri Tingkir Lor 02, khususnya tematik kelas 4 peserta didik mengalami masalah pada keterampilan kolaboratif. Maka pada siklus I dan siklus II dalam penelitian diperoleh data sebagai berikut:

Tabel 1 Distribusi Frekuensi Siklus I dan Siklus II

\begin{tabular}{cccccc}
\hline Interval & Kategori & f1 & $\begin{array}{c}\text { Siklus I } \\
\text { Persentase } \\
(\%)\end{array}$ & f1 & $\begin{array}{c}\text { Siklus II } \\
\text { Persentase } \\
(\%)\end{array}$ \\
\hline$\geq 81$ & Sangat Tinggi & 17 & 51.52 & 29 & 87.88 \\
$61-80$ & Tinggi & 13 & 39.39 & 2 & 6.06 \\
$41-60$ & Cukup & 3 & 9.09 & 2 & 6.06 \\
$21-40$ & Rendah & 0 & 0.00 & 0 & 0.00 \\
$\leq 20$ & Sangat & 0 & 0.00 & 0 & 0.00 \\
\hline \multicolumn{7}{c}{ Jumlah } & 33 & $100 \%$ & 33 & $100 \%$ \\
\hline
\end{tabular}


Berdasarkan table diatas terlihat peningkatan keterampilan kolaboratif pada konndisi siklus I dengan penerapan model pembelajaran Teams Games Tournament menunjukkan bahwa 17 dari 33 peserta didik atau sebesar 51,52\% mencapai kategori sangat tinggi, 13 dari 33 peserta didik atau sebesar $39,39 \%$ mencapai kategori tinggi dan 3 peserta didik atau 9,09\% masih dalam kategori rendah dalam berkolaborasi. Sedangkan pada siklus II diperoleh data $87,88 \%$ mencapai kategori sangat tinggi dan 2 peserta didik atau $6,06 \%$ mencapai kategori tinggi serta 2 peserta didik atau 6,06\% mencapai kategori cukup.

Lebih jelasnya mengenai perolehan hasil keterampilan kolaboratif peserta didik dapat dilihat pada grafi di bawah ini:

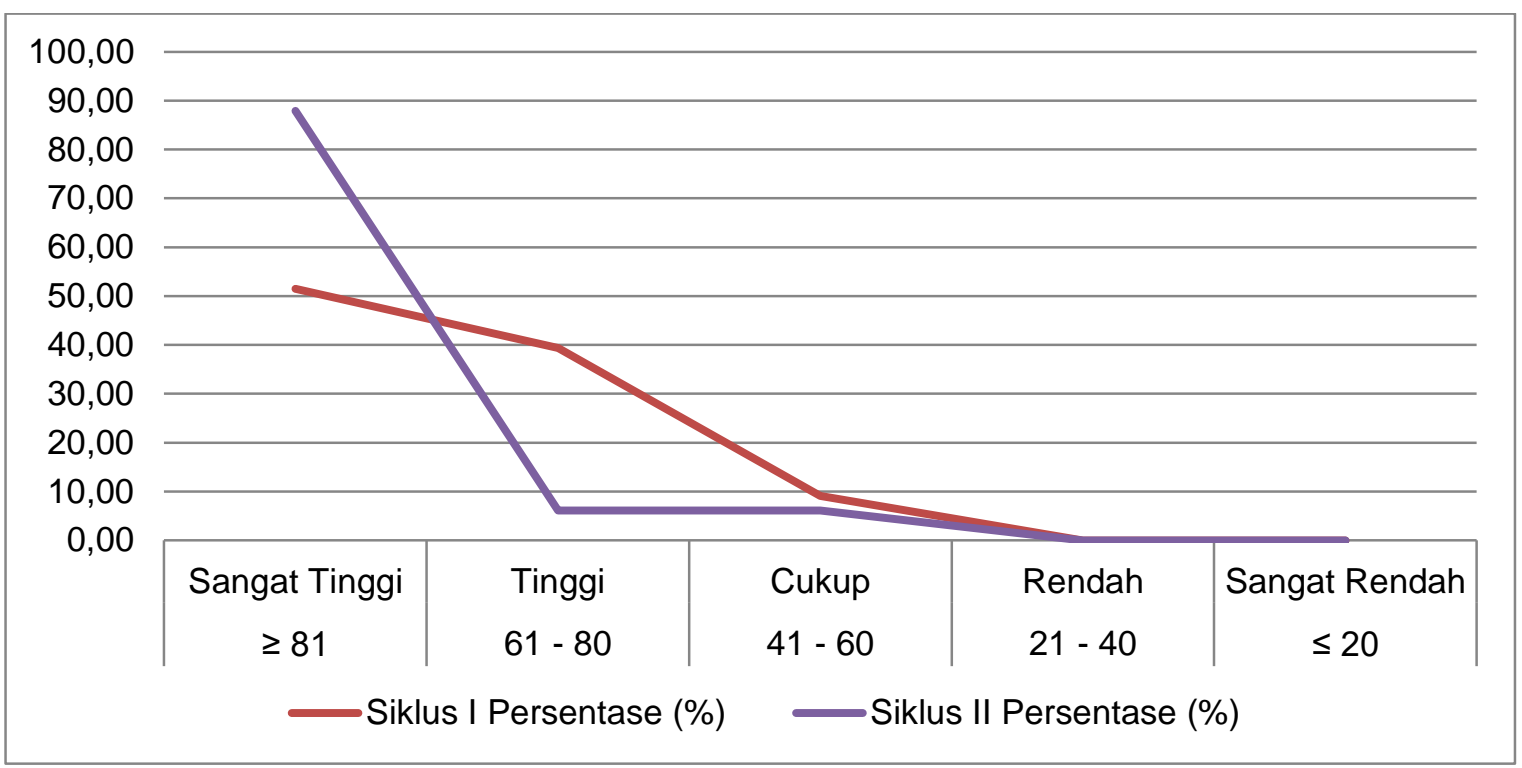

Grafik 1. Distribusi Frekuensi Siklus I dan Siklus II

Setelah dilakukan pengamatan saat proses pembelajaran pada siklus I dan Siklus II diperoleh data perbandingan hasil penelitian dalam table :

Tabel 2 Perbandingan Persentase Rata-rata Siklus I dan II

\begin{tabular}{ccc}
\hline $\begin{array}{c}\text { Rata-rata } \\
\text { Keterampilan } \\
\text { Kolaboratif } \\
\text { Siklus I }\end{array}$ & $\begin{array}{c}\text { Rata-Rata } \\
\text { Keterampilan } \\
\text { Kolaboratif } \\
\text { Siklus II }\end{array}$ & $\begin{array}{c}\text { Peningkatan } \\
\%\end{array}$ \\
\hline 78,22 & 93,18 & 16,05 \\
\hline
\end{tabular}

Berdasarkan table rata-rata siklus I dan II terlihat peningkatan persentase rata-rata keterampilan kolaboratif sebesar $16,05 \%$.

Berdasarkan distribusi tabel peningkatan persentase rata-rata keterampilan kolaboratif pada tabel persentase rata-rata dapat diketahui peningkatan skor minimum, skor 
maksimum, serta skor rata-rata pada siklus I, siklus II yang ditunjukkan pada gambar berikut :

Tabel 3 Tabel Statistik Deskriptif

\begin{tabular}{cccc}
\hline Siklus & $\begin{array}{c}\text { Rata- } \\
\text { Rata }\end{array}$ & $\begin{array}{c}\text { Nilai } \\
\text { Tertinggi }\end{array}$ & $\begin{array}{c}\text { Nilai } \\
\text { Terendah }\end{array}$ \\
\hline I & 78.22 & 93.75 & 50 \\
II & 93.18 & 100 & 56.25 \\
\hline
\end{tabular}

Pada tabel 3 diatas menunjukkan adanya peningkatan keterampilan kolaboratif disetiap siklus. Nilai tertinggi pada siklus I sebesar 93,75 dan nilai terendah sebesar 50 dengan nilai rata-rata klasikal sebesar 78,22. Skor tertinggi pada siklus II sebesar 100 dan skor terendah sebesar 56,25 dengan skor rata-rata klasikal adalah $93,18$.

Peningkatan tersebut dapat dilihat berdasarkan rata-rata hasil keterampilan kolaboratif pada siklus I sebesar 78,22 menjadi 93,18 pada siklus II. Penerapan model Teams Games Tournament dapat meningkatkan persentase keterampilan kolaboratif.

\section{Pembahasan}

Implementasi model pembelajaran Teams Games Tournament (TGT) memberikan gambaran penerapan tema 8 Daerah Tempat Tinggalku subtema 2 Keunikan Daerah Tempat
Tinggalku muatan Bahasa Indonesia, IPS dan PPKn, pembelajaran yang memberikan kesan berbeda. Suasana belajar yang menyenangkan dan tumbuhnya semangat belajar peserta didik karena adanya kegiatan permainan dan pertandingan memicu peserta didik dalam bersaing untuk menjawab soal-soal yang diberikan oleh peneliti. Hal ini sejalan dengan pendapat Slavin (2009:163) bahwa, model pembelajaran kooperatif Times Games Turnament (TGT) merupakan model pembelajaran yang menggunakan turnamen akademik dan menggunakan kuis-kuis, pada peserta didik akan berlomba-lomba sebagai perwakilan dari tim mereka dengan anggota tim lain untuk memenangkan permainan dan semua peserta didik ikut berperan aktif dalam tournament. Sehingga dalam kegiatan pembelajaran mampu meningkatkan keterampilan kolaboratif peserta didik dalam berkelompok.

berdasarkan hasil penelitian yang dilakukan oleh Vivin Putri Devi, Wahyudi, Endang Indarini (2018: 1620), penelitian yang dilakukan oleh Keke Citra Wahyu Avisca, Mawardi, dan Suhadi Astuti (2018: 129-138), penelitian yang dilakukan oleh Primadya Anantyarta dan Ririn Listya 
Ika Sari (2017:33), penelitian yang dilakukan oleh Eka Vasia Anggis (2016:493) bahwa dilakukan penelitian dengan model pembelajaran yang mengandung unsur kerjasama dalam berkelompok, dapat meningkatkan keterampilan Kolaboratif peserta didik. Model pembelajaran Teams Games Tournament (TGT) merupakan salah satu pembelajaran yang dilakukan secara berkelompok.

Penelitian yang senada dengan model pembelajaran yang digunakan oleh peneliti yaitu penelitian yang dilakukan oleh Suciyani Suaeb (2018: 146), selanjutnya adalah penelitaian yang dilakukan oleh Rima Yusi Christian, Mawardi dan Suhandi Astuti (2018: 75), Selain itu Ujiati Cahyaningsih (2017: 1-5). Begitu pula dengan Sri Wilujeng (2013: 45-53). Anisa Eka Pratiwi (2018: 338-346). Penelitian selanjutnya yaitu Siti Maisaroh (2011: 150-169). Begitu juga dengan penelitian Siti Era Harahap (2018: 101-109). Selanjutnya Kadek Yuni Artati (2017: 1-11). Berdasarkan penelitian yang senada dengan model pembelajaran yang digunakan oleh peneliti mampu meningkatkan hasil belajar peserta didik, hasil belajar merupakan dampak dari keberhasilan meningkatnya

keterampilan kolaboratif.

Dari uraian diatas maka dapat diperoleh hasil penelitian yang membuktikan bahwa penerapan model pembelajaran kooperatif Teams Games Tournament (TGT) dapat meningkatkan keterampilan kolaboratif. Rata-rata hasil keterampilan kolaboratif melalui penerapan model pembelajaran Teams Games Tournament pada siklus I 78,22 mengalami peningkatan menjadi 93,18 pada siklus II sehingga diperoleh persentase peningkatan keterampilan kolaboratif dari siklus I ke siklus II adalah 16,05\%.

\section{E. Kesimpulan}

Implementasi model pembelajaran Teams Games Tournament meningkatkan keterampilan kolaboratif pada peserta didik kelas 4 SD Negeri Tingkir Lor 02 tahun pelajaran 2018/2019 rata-rata hasil keterampilan kolaboratif siklus I sebesar 78,22, pada siklus II meningkat menjadi 93,18. Berdasarkan uraian diatas dapat disimpulkan bahwa penerapan model Teams Games Tournament (TGT) dapat meningkatkan keterampilan kolaboratif. 
Berdasarkan simpulan hasil penelitian tindakan kelas bahwa Implementasi model pembelajaran Teams Games Tournament (TGT) dalam meningkatkan keterampilan kolaboratif pada peserta didik kelas 4 SD Negeri Tingkir Lor 02 tahun pelajaran 2018/2019 maka penulis menyarankan agar peserta didik melakukan kegiatan yang berkaitan dengan kolaboratif. Bagi guru hendaknya menggunakan penerapan model Teams Games Tournament (TGT) sebagai alternatif dalam meningkatkan kualitas pembelajaran di dalam sekolah. Bagi peneliti selanjutnya dapat menggunakan hasil penelitian ini untuk melengkapi kelemahan dari penelitian yang dilakukan sebelumnya.

\section{DAFTAR PUSTAKA}

Anggis, E, V. (2016). Penerapan Model Kooperatif JIGSAW berbasis Lesson Study untuk Meningkatkan Keterampilan Kolaboratif dan Hasil Belajar Kognitif.Proceeding Biology Education Conference.13(1), 493497.

Artati, K, Y. Agung, A, A, G. Wibawa, C. (2017). Pengaruh Model Pembelajaran Kooperatif Tipe TGT Terhadap Hasil Belajar IPA Siswa Kelas V SD. E-Journal PGSD Universitas Pendidikan Ganesha. 5(2), 1-11.
Aviska, K, C, W. Mawardi, Astuti, S. (2018). Peningkatan Critical Thingking dan Collabotartive Skill Matematika Melalui Model Grup Invertigation. Naturalistic: Jurnal Kajian Penelitian Pendidikan dan Pembelajaran. 2(2), 129-138.

Cahyaningsih, U.(2017). Pengaruh Model Pembelajaran Kooperatif Tipe Team Games Tournament (TGT) Terhadap Hasil Belajar Matematika Siswa SD. Jurnal Cakrawala Pendas.3(1), 1-5.

Christian, R. Mawardi. Astuti S. (2018). Perbedaan Hasil Belajar Matematika Menggunakan Model Student Team Achievment Divisions (Stad) dan Teams Game Tournament (TGT) Siswa Kelas 4 SD.JTIEE. 2(1), 75-84.

Devi, V,P. Wahyudi. Indarini, E. (2018). Penerapan Metode Numbered Heads Together Berbantuan Puzzle untuk Meningkatkan Keterampilan Kolaborasi dan Hasil Belajar Tema 8 Daerah Tempat Tinggalku Siswa Kelas 4 SDN 3 Kuripan. KALAM CENDEKIA.6(3.1), 16-20.

Hamdani. 2011. Strategi Belajar Mengajar. Bandung: Pustaka Setia. Harahap, S.(2018). Meningkatkan Hasil Belajar PPKn Melalui Model Pembelajaran TGT (Team Games Tournament) Siswa Kelas 5 SD Negeri $\quad 164525 \quad$ Tebing Tinggi.Elementary School Journal.8(2), 101-109.

Huda, Miftahul. 2018. Model-Model Pengajaran dan Pembelajaran: Isuisu Metodis dan Paradigmatis. Yogyakarta: Pustaka Pelajar

Maisaroh, S. (2011). Upaya Peningkatkan Motivasi dan Prestasi Belajar IPS Melalui Model Pembelajaran Kooperatif Tipe Teams Games Tournament. Jurnal Pendidikan Ekonomi Sinamika Pendidikan. 6(2), 151-169. 
Pamungkas, D, A. (2017). Penerapan Model Pembelajaran Kooperatif Tipe Teams Games Tournament (TGT) Terhadap Pencapaian Hasil Belajar Siswa pada Kompetensi Memahami Prinsip Pengoperasian Sistem Pengendali Elektronik Kelas Xi SMK Hamong Putera 2 Pakem. E-Journal Universitas Negeri Yogyakarta. 7(2), 107-117.

Pratiwi, A, E. Prihatni, Y. (2018). Pengaruh Model Pembelajaran Kooperatif Tipe Teams Games Tournament Terhadap Prestasi Belajar IPA Siswa Kelas V Sd Negeri Gedongtengen Yogyakarta Tahun Ajaran 2016/2017. Trihayu: Jurnal Pendidikan Ke-SD-an.4(2), 338-346.

Permendikbud nomor 22 tahun 2016 tentang Standar Proses Pendidikan Dasar dan menengah Kurikulum 2013

Rusman. 2012. Model-model Pembelajaran. Jakarta: Raja Grafindo

Slavin, Robert.E, Cooperative Learning: Teori, Riset dan Praktik, Penerjemaah: Lita, Bandung: Nusa Media, 2009.

Suaeb, S. Degeng,I, N, S. Amirudin, A. .(2018).Meningkatkan Hasil Belajar
IPS Siswa Kelas $V$ melalui Penerapan Pembelajaran Kooperatif Model Teams Games Turnament (TGT) Berbantuan Media Tebak Gambar.Jurnal Pendidikan:Teori, Penelitian dan Pengembangan.3(1), 146-154.

Wahyuni, K, M. Putra M, Darsana I, W. (2014). Pengaruh Model Pembelajaran Team Game Turnament (TGT) Melalui Variasi Reinforcement Terhadap Hasil Belajar IPS Siswa Kelas V SD Gugus III Batuan Sukawati Tahun Pelajaran 2013/2014. Jurnal Mimbar $P G S D$ Universitas Pendidikan Ganesha. 2(1), 1-10.

Warsono,Harianto. 2013.

Pembelajaran Aktif .Bandung : PT

Remaja Rosda Karya

Wilujeng,S.(2013).Peningkatan Aktivitas dan Hasil Belajar Siswa Melalui Model Teams Games Tournament (TGT).Journal of Elementary Education.2(1)

Zubaidah, S. (2018). Keterampilan Abad Ke-21: Bagaimana Membelajarkan dan Mengaksesnya. Jurnal Biologi-FMIPA-Universitas Negeri Malang. 